\title{
Timing of Fungicide Applications for Botrytis cinerea Based on Development Stage of Strawberry Flowers and Fruit
}

\author{
J. C. Mertely, S. J. MacKenzie, and D. E. Legard, University of Florida, Gulf Coast Research and Education \\ Center, 13138 Lewis Gallagher Road, Dover 33527
}

\begin{abstract}
Mertely, J. C., MacKenzie, S. J., and Legard, D. E. 2002. Timing of fungicide applications for Botrytis cinerea based on development stage of strawberry flowers and fruit. Plant Dis. 86:1019-1024.

During the 1999-2000 and 2000-2001 growing seasons, field experiments were conducted to identify the developmental stage(s) of strawberry flowers and fruit that requires fungicide applications to control Botrytis fruit rot. Fenhexamid, a protectant fungicide, was applied to individual newly opened flowers or fruit of cultivar Sweet Charlie at defined intervals after anthesis. In 1999-2000, a single application of fenhexamid at anthesis controlled Botrytis fruit rot as well as multiple weekly applications beginning at anthesis. During both seasons, disease control deteriorated as applications were delayed 7 and 14 days after anthesis. This trend was described by linear regression equations relating the time of application to Botrytis fruit rot incidence. Additional treatments tested the effects of emasculation and petal removal 3 to 7 days after anthesis. Emasculation significantly reduced disease incidence in 2000-2001. Petal removal produced modest but significant reductions in 1999-2000, but not in 2000-2001. These results demonstrate that strawberry flowers are more susceptible to Botrytis cinerea than green fruit, and suggest that stamens are the principal infection court. Fungicide applications should focus on peak bloom periods to minimize fungicide use and optimize control of preharvest Botrytis fruit rot. During these periods, applications should be made at close intervals ( $\leq 7$ days) to minimize losses to Botrytis.
\end{abstract}

Additional keywords: Fragaria $\times$ ananassa, gray mold, ontogeny, phenology

Botrytis fruit rot, caused by the fungus Botrytis cinerea Pers.:Fr., is an important disease of strawberry in both annual and perennial cropping systems. B. cinerea produces large, brown lesions, typically at the stem end of ripening fruit $(23,27)$. The fungus sporulates in the presence of free water (26), covering lesions with a gray mass of conidia and conidiophores. During commercial harvest operations, visibly infected fruit are either left on the plant or picked and discarded in the field. These preharvest losses to Botrytis fruit rot may reach or exceed $50 \%$ during epidemics in commercial fields $(9,11)$ and experimental studies $(20,29)$. B. cinerea also causes significant losses during shipping and marketing (7), making it one of the most economically important pathogens of strawberry.

Botrytis fruit rot is usually initiated by germinating conidia that infect strawberry flowers $(6,11,23)$. Conidia are produced in large quantities on dead and dying foliage

Corresponding author: James C. Mertely E-mail: jcmert@ufl.edu

Florida Agricultural Experiment Station Journal Series No. R-08808.

Accepted for publication 16 May 2002.

Publication no. D-2002-0719-01R

(C) 2002 The American Phytopathological Society throughout the growing season (4). In annual production systems with multiple flowering cycles and an extended harvest period, conidia produced on diseased ripening fruit and small, mummified fruit may contribute to inoculum buildup during epidemics (28). Newly opened flowers are highly susceptible to $B$. cinerea $(13,28)$. Infection is favored by moderate temperatures $\left(15\right.$ to $\left.25^{\circ} \mathrm{C}\right)$, high humidity, and prolonged surface wetness $(6,29)$. These environmental conditions are conducive to rapid germination and penetration of pistils, petals, and stamens $(5,12,13,23)$. The fungus grows rapidly through the anther and filament of the stamen, but more slowly through the stigma and style of the pistil (5). Stamens are considered the principal infection court leading to Botrytis fruit rot $(23,24)$. Following penetration, $B$. cinerea colonizes the infected flower part or may become quiescent $(5,23)$. As the fruit matures, the pathogen invades the receptacle, and lesions become visible on the stem end of the fruit $(5,23)$.

Fruit infections are also associated with adhering petals and direct contact with other diseased fruit $(11,25,28)$. In Florida, most strawberry petals abscise and fall away from the fruit within a week after anthesis (J. C. Mertely, unpublished data). However, some petals adhere to the surface of the receptacle or become lodged under the calyx, remaining in contact with the fruit surface indefinitely (11). Botrytis infections have been observed originating from adhering petals (11; D. E. Legard, unpublished data). Necrotic adhering petals retain moisture and represent a saprophytic food base, which may facilitate direct colonization of the receptacle by the fungus $(11,23)$. Healthy fruit also can be infected through direct contact with diseased fruit in the field or in storage containers $(3,18,25,28)$. Direct infection of intact fruit by germinating conidia is rare $(11,23)$. However, wounded fruit inoculated with $1 \times 10^{6}$ conidia per $\mathrm{ml}$ showed "appreciable lesion development" after 7 days storage at $5^{\circ} \mathrm{C}(25)$.

Given the importance of flowers in the infection process, proper timing of fungicide applications is essential for successful chemical control of Botrytis fruit rot. Fungicides should be applied when strawberry plants are flowering. In perennial systems, this is a relatively short period lasting from 2 to 4 weeks in the spring. The efficacy of fungicide applications during this period has been validated by comparing bloom applications to untreated controls, and to programs of longer duration. Bloom applications reduced the incidence of Botrytis fruit rot $(1,2,21,29)$ and often controlled the disease as well as application programs extending into the fruiting and harvest periods $(1,2,15,29)$. Bennett (2) found that three or four applications of chlorothalonil or dichlofluanid controlled Botrytis fruit rot better than two, but all applications were made during the flowering period. Bloom applications have also been associated with reductions in postharvest Botrytis fruit rot, but less consistently than in preharvest studies $(8,14,21)$.

In annual winter production systems in Florida, the control of Botrytis fruit rot is complicated by a lengthy flowering period that begins in October or November and continues until the end of harvesting in March or April. During a typical season, the majority of fruit originate from two peak bloom periods. For cultivar Sweet Charlie, the first peak extends from late November to mid-December, and the second from mid-January to mid-February. When fungicide applications are restricted to these peak bloom periods, Botrytis disease control is less than optimal (20). Weekly applications of captan or thiram over the entire growing season (16 to 22 applications) controlled preharvest and postharvest Botrytis fruit rot better than four applications of iprodione during the peak bloom periods $(3,20)$. However, two 
applications of iprodione during the second bloom period significantly reduced preharvest disease and increased yields during the latter half of the season (20). In other experiments, late-season bloom applications of iprodione also reduced the incidence of postharvest disease (3).

Fungicide efficacy trials on strawberry are typically conducted by spraying plots repeatedly during the flowering and fruiting period. Treatments are customarily applied on calendar schedules; so optimum spray intervals are rarely determined. Occasionally, the number and timing of applications are manipulated to identify periods in the crop cycle when fungicide applications are effective. Unfortunately, these experiments do not identify developmental states of strawberry flowers and fruit that benefit most from fungicide protection. Such epidemiological information is essential for the improvement of Botrytis fruit rot management programs, especially in annual strawberry.

In this study, fungicide efficacy was evaluated in relation to strawberry flower and fruit development by applying fenhexamid to individual flowers and fruit in the field at specific intervals after anthesis (flower opening). The hydroxyanilide fungicide fenhexamid was used as a representative protectant fungicide (17). Petal removal and emasculation were also carried out to test the relative importance of petals and other flower parts as potential infection courts. A preliminary report of this research has been published (22).

\section{MATERIALS AND METHODS}

Field experiments were carried out during the 1999-2000 and 2000-2001 strawberry growing seasons at the University of Florida's Gulf Coast Research and Education Center in Dover. Similar cultural practices were employed both seasons. Land preparation began in September with rotavation of the soil and incorporation of 6:2:8 starter fertilizer broadcast at 570 $\mathrm{kg} / \mathrm{ha}$. Beds (15 to $18 \mathrm{~cm}$ tall and $75 \mathrm{~cm}$ wide on $1.2-\mathrm{m}$ centers) were formed, fumigated with a mixture of $67 \%$ methyl bromide and $33 \%$ chloropicrin at 350 $\mathrm{kg} / \mathrm{ha}$, and covered with black plastic mulch over drip irrigation tape.

In October, bare-root runner plants from Canada were transplanted into two offset rows per bed. The rows were $30 \mathrm{~cm}$ apart, with plants set $38 \mathrm{~cm}$ apart within the rows. To facilitate establishment, overhead sprinklers irrigated the plants during the day for 10 to 12 days following transplant. Cultivar Sweet Charlie was used in all experiments because it is highly susceptible to Botrytis fruit rot and grown extensively in Florida (19). After establishment, irrigation and fertigation were provided twice weekly through drip tape, and freeze protection was provided by overhead sprinklers when necessary. Overhead sprinklers were also used occasionally to enhance disease development during dry periods. Spider mite and insect populations were monitored by a scouting program and controlled by the application of predatory mites, miticides, and insecticide sprays. During the 1999-2000 season only, experimental areas were treated with captan (Captan 80WP; $3.4 \mathrm{~kg}$ a.i./ha in 940 liters of water per ha) on a weekly schedule until 2 weeks before the start of the bloom treatments.

During the first experiment of the 19992000 season, individual flowers and fruit were treated with fenhexamid (Elevate 50WDG; $0.9 \mathrm{~g}$ a.i./liter) by spraying to runoff with a plastic misting bottle. In subsequent experiments, fenhexamid was applied with a hand-held, aerosol sprayer (Preval Sprayer, Precision Valve Corporation, Yonkers, NY), which appeared to improve coverage and reduce spray volume. Spraying to runoff with this device required approximately $0.25 \mathrm{ml}$ per flower and up to $0.60 \mathrm{ml}$ per older fruit. The following treatments were evaluated in 19992000 and 2000-2001: (i) an untreated control; (ii) fenhexamid applied at anthesis (0 days); (iii) fenhexamid applied 3 days after anthesis (DAA) (2000-2001 only); (iv) fenhexamid applied 7 DAA; (v) fenhexamid applied 14 DAA; (vi) fenhexamid applied weekly from anthesis to harvest (0, 7, 14, and 21 DAA) (1999-2000 only); (vii) petal removal 7 DAA (1999-2000) or 3 to 4 DAA (2000-2001); and (viii) emasculation, i.e., manual removal of a circular ring of tissue including sepals, petals, and stamens from the base of the flower with forceps (10) 3 to 4 DAA (2000-2001 only).

1999-2000 season. Six treatments were evaluated in three replicate experiments during the 1999-2000 season. The experiments were conducted in separate blocks of 'Sweet Charlie' planted between 11 and 18 October 1999. The blocks were five to seven beds wide and $45 \mathrm{~m}$ long. Each experiment was initiated by locating and tagging 300 flowers, each on a different plant in the experimental block. Flowers were tagged within $24 \mathrm{~h}$ of flower opening by attaching sequentially numbered merchandise tags $(2.8 \times 4.4 \mathrm{~cm})$ to the pedicels with their accompanying cotton strings. Fifty flowers were assigned to each treatment using a random number table.

Flowers for the first experiment were tagged on 8 December 1999 during the first bloom period. Fruit developing from these flowers were examined 7 DAA, 14 DAA, and at harvest to determine when symptoms of Botrytis fruit rot were visible. Harvesting began on 30 December with the first appearance of ripe fruit and continued at 2-day intervals until 3 January, when all the fruit had been picked. Healthy pink to red fruit and diseased fruit at any developmental stage were picked during each harvest. Harvested fruit were classified into three categories: healthy (undamaged and lesion free); damaged (injured by birds, insects, or pathogens other than $B$. cinerea); or diseased (with lesions caused by $B$. cinerea). The interval from anthesis to harvest was recorded for each healthy fruit. Diseased fruit were examined under a dissecting microscope to confirm the presence of Botrytis conidiophores and conidia. When sporulation was lacking, fruit were placed in a humidity chamber, incubated for two diurnal cycles of $16 \mathrm{~h}$ light $\left(20^{\circ} \mathrm{C}\right)$ and $8 \mathrm{~h}$ darkness $\left(16^{\circ} \mathrm{C}\right)$, and reexamined.

The second and third experiments were initiated during the second bloom period on 2 and 14 February 2000, respectively. In experiment three, overhead irrigation was applied four times (23 and 24 February, 4 and 5 March) to encourage disease development during a cool, dry period. Harvesting was carried out from 26 February to 3 March in experiment two, and from 5 to 9 March in experiment three. The procedures followed in these two experiments were identical to those in experiment one, except for the change to a pressurized aerosol sprayer and the use of overhead irrigation in experiment three.

Botrytis fruit rot incidence data from 1999-2000 were analyzed by logistic regression using the SPSS statistical package (SPSS, Inc., Chicago, IL). Logistic regression was used for these analyses due to the binary nature of the response variable obtained from the completely randomized experimental design. Since treatment $x$ experiment interactions were not significant, disease incidence data from the three experiments were combined in the analysis. Treatment effects were classified as quantitative or qualitative, and each group of treatments was analyzed separately. Treatment effects related to the quantitative variable time (where $t=$ number of days after anthesis when fenhexamid was applied) were analyzed with the logistic regression model $\ln$ (odds) $=a+\delta_{i}+\beta(t)$, where $a$ is a constant, $\delta_{i}$ the experiment effect, and $\beta$ the time effect. Treatment effects related to qualitative or categorical variables (i.e., petal removal, weekly applications of fenhexamid, and an untreated control) were analyzed using the logistic regression model $\ln$ (odds) $=a+\delta_{i}+\alpha_{i}$, where $a$ is a constant, $\delta_{i}$ is the experiment effect, and $\alpha_{i}$ is the treatment effect. Model fit was assessed using the Hosmer and Lemeshow goodness-of-fit test. Conditional probability estimates for petal removal and weekly fenhexamid treatments were obtained by contrasts with the untreated control. For clarity and ease of presentation, Botrytis fruit rot incidence was expressed in percent and obtained by dividing the number of diseased fruit by the total number of healthy, damaged, and diseased fruit harvested in each treatment.

2000-2001 season. Seven treatments were evaluated in three replicate experiments carried out in 2000-2001. The experiments were conducted in separate blocks consisting of five beds each of cul- 
tivar Sweet Charlie planted on 6, 13, and 20 October 2000. Tagging and locating individual flowers and fruit for observations and treatment was simplified by organizing the treatments into a randomized complete block design with five replicates, each consisting of a single bed. Treatments were assigned at random to individual plots within a bed. Plot size was determined by the length of bed needed to produce 12 newly opened flowers at the beginning of each experiment, with a maximum of one experimental flower per plant. Plots were separated by 1.5 to $2.0 \mathrm{~m}$ of bed where no flowers were tagged. Selfadhesive labels (Tough-Tags, Diversified Biotech, Boston, MA) were printed with treatment and replicate numbers and attached to the pedicels. Flowers were tagged on 6, 14, and 21 February 2001 for experiments 1,2 , and 3 , respectively. No experiments were initiated during the first peak bloom due to the relatively low incidence of Botrytis fruit rot that occurred during the first experiment of 1999-2000, which is typical for this time of the season (19).

Green fruit were examined at 7 and 14 DAA for visible symptoms of Botrytis fruit rot. In experiments 2 and 3, overhead irrigation was applied four to five times between 9 and 18 DAA to accelerate disease development when warmer weather was anticipated. Harvesting began on 26 February, 6 March, and 14 March and ended on 2, 12, and 18 March for the first, second, and third experiments, respectively. Ripe and diseased fruit were picked every 2 days during the harvest periods. The numbers of healthy and diseased fruit, and age of healthy fruit at harvest were recorded for each plot. Lesions caused by B. cinerea were confirmed and disease incidence was calculated as in 1999-2000.

The three experiments from the 20002001 season were combined for analysis since there were no significant treatment $x$ experiment interactions for the incidence of Botrytis fruit rot. Treatments were divided into two groups based on quantitative or qualitative effects and analyzed in SAS (SAS Institute, Cary, NC). An analysis of covariance was used to evaluate the effects of quantitative treatments (applica- tions of fenhexamid at $0,3,7$, and 14 DAA) and to obtain parameter estimates for regressions of disease incidence over time. An analysis of variance was conducted on the qualitative treatments (emasculation, petal removal, and control) using the PROC GLM procedure with experiment, treatment, and replicate as classification variables. Multiple comparisons of treatment means were made with Fisher's protected LSD. Disease incidence data were transformed by an arcsine square root expression prior to analysis.

\section{RESULTS}

1999-2000 season. In 1999-2000, the first experiment was initiated during the first peak bloom period in December, while experiments 2 and 3 began during the second peak bloom period in February. Seasonal temperatures prevailed, with mean daily temperatures averaging 17.0, 16.6 , and $19.5^{\circ} \mathrm{C}$ during the three respective experiments. Moderate rainfall (1.1 to
$1.7 \mathrm{~cm} /$ day) occurred 7, 10, and 11 DAA in the first experiment, while no precipitation exceeding $0.5 \mathrm{~cm} /$ day occurred during experiments 2 and 3 . The incidence of Botrytis fruit rot was moderate in the first experiment and relatively severe in experiments 2 and 3. Disease incidence in the untreated controls ranged from $18.8 \%$ in the first experiment to $48.0 \%$ in the third (Table 1).

Disease incidence increased as the time after anthesis that fenhexamid was applied increased (Table 2). This trend was described by a linear regression model, which indicated a significant positive relationship between Botrytis incidence and time of application $(P=0.0001)$ (Table 3$)$. The addition of a quadratic term did not significantly improve the model. In the first experiment, the odds of being diseased (i.e., the proportion of diseased fruit divided by the proportion of healthy fruit) were related to time by the equation $\ln$ (odds) $=$ $-4.566+0.2247(t)$, where $t=$ number of

Table 2. Effect of fenhexamid applications, emasculation, and petal removal on the incidence of Botrytis fruit rot in experiments conducted during the 1999-2000 and 2000-2001 strawberry growing seasons

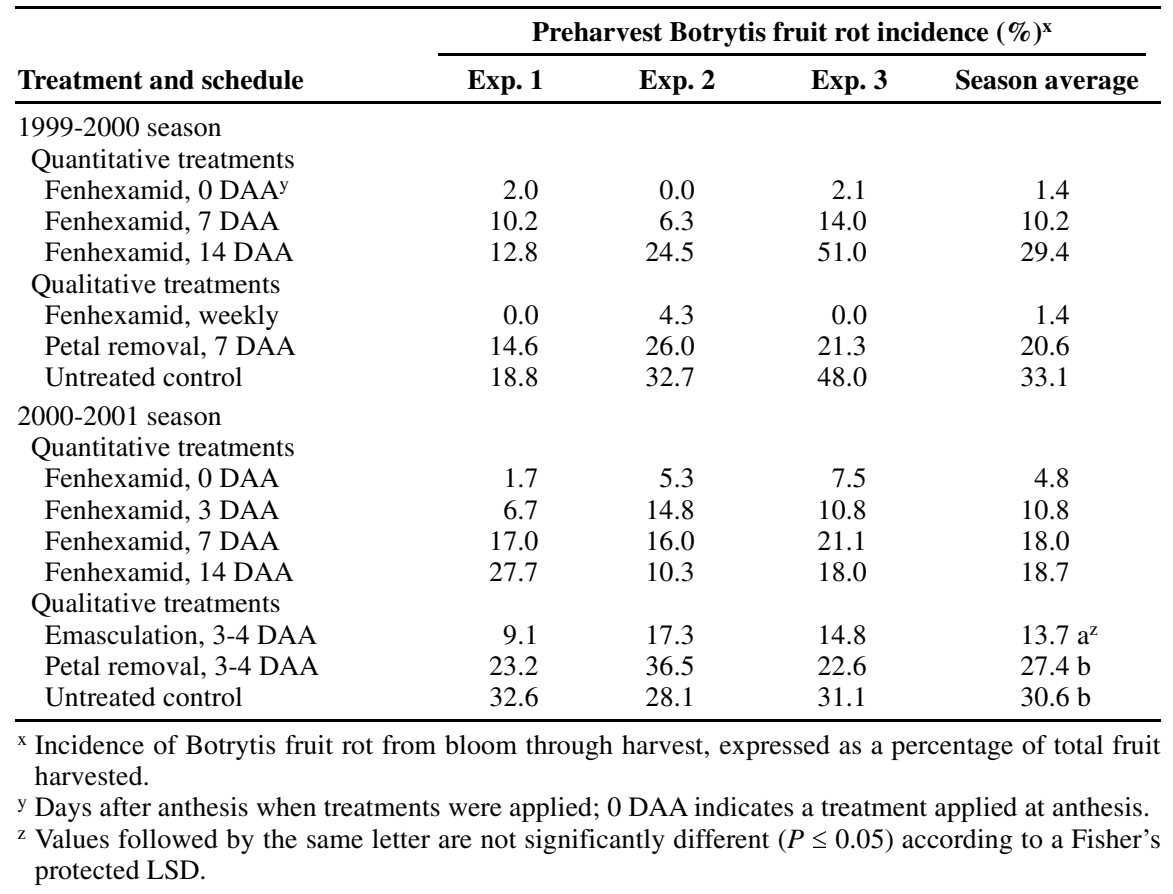

Table 1. Frequency distribution for the appearance of Botrytis fruit rot symptoms in untreated field-grown strawberry fruit at defined intervals after anthesis

\begin{tabular}{|c|c|c|c|c|c|c|c|}
\hline \multirow[b]{2}{*}{ Season } & \multirow[b]{2}{*}{ Exp. } & \multicolumn{4}{|c|}{ Botrytis incidence $(\%)^{\mathrm{x}}$} & \multirow{2}{*}{$\begin{array}{c}\text { Cumulative } \\
\text { preharvest } \\
\text { incidence (\%) }\end{array}$} & \multirow{2}{*}{$\begin{array}{c}\text { Average days } \\
\text { to harvest }^{\mathrm{z}}\end{array}$} \\
\hline & & 0 DAA (anthesis) $)^{y}$ & 0 - 7 DAA & 7 - 14 DAA & 14 DAA to harvest & & \\
\hline $1999-2000$ & 1 & $12 / 8 / 99$ & 0.0 & 16.7 & 2.1 & 18.8 & 23.3 \\
\hline $1999-2000$ & 2 & $2 / 02 / 00$ & 0.0 & 4.1 & 28.6 & 32.7 & 26.0 \\
\hline $1999-2000$ & 3 & $2 / 14 / 00$ & 0.0 & 16.0 & 32.0 & 48.0 & 21.4 \\
\hline $2000-2001$ & 1 & $2 / 06 / 01$ & 0.0 & 0.0 & 32.7 & 32.7 & 20.5 \\
\hline $2000-2001$ & 2 & $2 / 14 / 01$ & 0.0 & 1.8 & 26.3 & 28.1 & 22.4 \\
\hline $2000-2001$ & 3 & $2 / 21 / 01$ & 0.0 & 3.4 & 27.6 & 31.1 & 22.0 \\
\hline
\end{tabular}

${ }^{\mathrm{x}}$ Fruit were examined for symptoms of Botrytis fruit rot 7 days after anthesis (DAA), 14 DAA, and at harvest (20 to 28 DAA).

y Experiments were initiated on the indicated dates by tagging flowers within $24 \mathrm{~h}$ of opening (anthesis).

${ }^{z}$ Overall means for all healthy fruit harvested in each experiment. 
days after anthesis that fenhexamid was applied. This relationship differed somewhat for experiments 2 and 3 , where the were -4.329 and -3.245 , respectively. The positive slope indicates increasing disease incidence over time, as shown by progressively higher levels of Botrytis fruit rot when applications were made 7 and 14 DAA (Table 2). incidence of Botrytis fruit rot compared with the untreated control (Table 2). Weekly applications of fenhexamid at 0,7 , 14, and 21 DAA limited disease incidence to $1.4 \%$, the same level provided by a single application of fenhexamid at anthesis. Weekly applications of fenhexamid reduced the odds of being diseased to 0.0274 times the level of the untreated control $(P$ $=0.0001)$ (Table 3). Petal removal reduced the odds of being diseased to 0.5146 times that in the untreated control (Table 3). While the latter reduction was relatively small, it was significant $(P=0.0152)$.

Strawberry fruit were examined for symptoms of Botrytis fruit rot 7 DAA, 14 parameter estimates for the $y$ intercept

Both qualitative treatments reduced the

DAA, and at harvest. Seven-day-old fruit were not visibly diseased, but small, solitary lesions characteristic of Botrytis infection were observed on 14-day-old fruit. A typical lesion occurred at the stem end of the fruit and was firm, brown, and lacked obvious fungal growth. In the first experiment, $16.7 \%$ of the untreated control fruit developed symptoms by 14 DAA (Table 1). An additional $2.1 \%$ developed lesions after 14 DAA, which were observed at harvest. In experiments 2 and 3, the majority of fruit developed symptoms after 14 DAA. Lesions were observed on these fruit at harvest, i.e., 20 to 28 DAA.

During the 1999-2000 season, the average time to harvest ranged from 21.4 days in experiment 3 to 26.0 days in experiment 2 (Table 1). Fruit maturation times were affected by experiment, i.e., time of season when the fruit developed, but not by treatment (data not shown). The largest difference in maturation time between treatments was 0.3 days.

2000-2001 season. In 2000-2001, all three experiments were initiated during the second peak bloom period in February, and

Table 3. Results from logistic regression analyses of Botrytis fruit rot incidence data from experiments conducted during the 1999-2000 strawberry growing season

\begin{tabular}{|c|c|c|c|c|c|c|}
\hline Factor & Category & Odds ratio & $\begin{array}{c}\text { Wald } \\
\text { statistic }\end{array}$ & df & $P$ (factor) & $\begin{array}{c}P(\text { Category } \\
\text { vs. reference) })^{\mathrm{w}}\end{array}$ \\
\hline \multicolumn{7}{|c|}{ Quantitative treatments ${ }^{x}$} \\
\hline \multirow[t]{4}{*}{ Experiment } & & & 15.2000 & 2 & 0.0005 & \\
\hline & Exp. 1 & $1.0000(\mathrm{ref})^{\mathrm{y}}$ & & & & \\
\hline & Exp. 2 & 1.2669 & 0.3084 & 1 & & 0.5787 \\
\hline & Exp. 3 & 3.7453 & 11.6714 & 1 & & 0.0006 \\
\hline Time & & $1.2520^{\mathrm{z}}$ & 38.9425 & 1 & 0.0001 & \\
\hline \multicolumn{7}{|c|}{ Qualitative treatments $\mathrm{x}$} \\
\hline \multirow[t]{4}{*}{ Experiment } & & & & 2 & 0.0133 & \\
\hline & Exp 1 & 1.0000 (ref) & & & & \\
\hline & Exp 2 & 2.2969 & & 1 & & 0.0176 \\
\hline & Exp 3 & 2.6764 & & 1 & & 0.0046 \\
\hline \multirow[t]{4}{*}{ Treatment } & & & & 2 & 0.0001 & \\
\hline & Control & 1.0000 (ref) & & & & \\
\hline & Fenhexamid & 0.0274 & & 1 & & 0.0001 \\
\hline & Petal removal & 0.5146 & & 1 & & 0.0152 \\
\hline
\end{tabular}

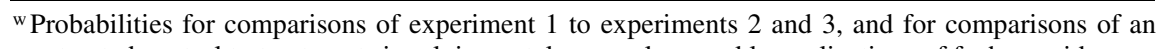
untreated control to treatments involving petal removal or weekly applications of fenhexamid.

x Separate analyses were performed for treatment effects classified as quantitative (days after anthesis for application of fenhexamid) and qualitative (untreated control, petal removal, and weekly fenhexamid applications).

${ }^{\mathrm{y}}$ ref $=$ reference category for contrasts.

${ }^{\mathrm{z}}$ Odds ratio for time (1.2520) represents the increase in odds of Botrytis fruit rot for each 1-day delay in application of fenhexamid after anthesis.

Table 4. Results from an analysis of covariance relating Botrytis fruit rot incidence in experiments conducted during the 2000-2001 strawberry-growing season to the time of application of fenhexamid

\begin{tabular}{lrcccc}
\hline Source $^{\mathbf{y}}$ & df & Sum of squares & Mean square & $\boldsymbol{F}$ value & $\boldsymbol{P}>\mathbf{F}$ \\
\hline Model & 3 & 0.5963 & 0.1988 & 4.41 & 0.0074 \\
Error & 56 & 2.5217 & 0.0450 & & \\
Total & 59 & 3.1181 & & & \\
Experiment & 2 & $0.0235^{\mathrm{z}}$ & 0.0117 & 0.26 & 0.7714 \\
Time & 1 & $0.5729^{\mathrm{z}}$ & 0.5729 & 12.72 & 0.0007 \\
\hline
\end{tabular}

$\mathrm{y}$ Time of fenhexamid application $(0,3,7$, and 14 days after anthesis) was considered a continuous covariate in a regression model relating Botrytis fruit rot (arcsine square root transformation of disease incidence) to experiment and time. The coefficient of determination $\left(R^{2}\right)$ for this model was 0.1913 .

${ }^{\mathrm{z}}$ Type III sum of squares. concluded in March. In Florida, this period is typically sunny with low rainfall and mild temperatures. No rainfall occurred during the first 26 days of the period (6 February to 3 March). The only significant precipitation $(4.8 \mathrm{~cm})$ fell on 4 March 2001, which coincided with the second and third experiments. Mean daily temperatures were unusually warm for the first two experiments $\left(20.8\right.$ and $21.0^{\circ} \mathrm{C}$, respectively) and unseasonably cool during the third $\left(19.8^{\circ} \mathrm{C}\right)$. Surprisingly, disease incidence was fairly uniform, ranging from 28.1 to $32.6 \%$ in the untreated controls of the three experiments (Table 2).

The linear regression model for the incidence of Botrytis fruit rot in the three experiments was highly significant $(P=$ $0.0074)$, with a coefficient of determination $\left(R^{2}\right)$ of 0.1913 (Table 4$)$. In partitioning the sums of squares, disease incidence was significantly affected by treatment, i.e., the number of days after anthesis when fenhexamid was applied $(P=0.0007)$. In experiment 3 , the transformed disease incidence $(y)$ was described by the equation $y=0.2185+0.0186(t)$. Equations for experiments 1 and 2 have the same slope as reference experiment 3 , and $y$ intercepts of 0.1719 and 0.1836 , respectively. Untransformed disease incidence data are reflected in these equations. A single application of fenhexamid at anthesis reduced the incidence of Botrytis fruit rot to $4.8 \%$ over the three experiments (Table 2). Delaying the initial application of fenhexamid 3, 7, or 14 DAA leads to progressively higher disease incidences. The positive slope of the linear regression equations and statistical significance of the linear model demonstrate this trend.

Emasculation, petal removal, and control treatments significantly affected the incidence of Botrytis fruit rot $(P=0.0035)$ according to the $F$ test for overall treatment effects. Disease incidence was lowest in the emasculation treatment $(13.7 \%)$ and highest in the untreated control $(30.6 \%$; Table 2). Petal removal did not significantly reduce disease incidence in 20002001.

In 2000-2001, 7-day-old fruit appeared healthy, and few 14-day-old fruit were visibly diseased (Table 1). Most cases of Botrytis fruit rot developed after observations made 14 DAA and were confirmed at harvest (20 to $25 \mathrm{DAA}$ ). The average time to harvest was $20.5,22.4$, and 22.0 days in experiments 1,2 , and 3 , respectively. Over the entire season, fruit maturation times were significantly affected by experiment, but not by treatment. The average difference in time to harvest for the most disparate treatments was only 0.4 days.

\section{DISCUSSION}

The efficacy of fenhexamid was significantly affected by the developmental stage of strawberry flowers and fruit at the time of application. A single application to 
newly opened flowers successfully controlled Botrytis fruit rot, while applications to green fruit 7 and 14 DAA were progressively less effective. The reduced efficacy of later applications of fenhexamid was evident in the positive slopes for regression equations describing the relationship between disease incidence and time of application. These results suggest that protectant fungicides should be applied as soon as the flowers open or within a few days of anthesis to effectively control Botrytis fruit rot.

Susceptibility to Botrytis fruit rot is influenced by the developmental stage of strawberry flowers and fruit $(13,23,25)$. Flowers inoculated in the white bud to full bloom stage developed more severe lesions than those inoculated in the green bud or petal drop stage (13). Inoculations of nonwounded fruit, on the other hand, did not cause Botrytis fruit rot $(11,25)$. These studies suggest that open flowers are the principal infection court and explain why fungicide applications to open flowers at anthesis are more effective than applications made to 7- or 14-day-old fruit.

During the 2000-2001 season, fenhexamid was applied 3 DAA to evaluate an additional time interval between anthesis and 7 DAA. Under Florida growing conditions, 3 DAA corresponds with the beginning of the petal drop stage in cultivar Sweet Charlie. By 7 DAA, most petals have abscised and the flowers have grown into small green fruit (J. Mertely, unpublished data). According to an overall regression equation using the mean $y$ intercept estimates for all three experiments, the predicted disease incidence $(y)$ increases from $3.6 \%$ when fenhexamid is applied at anthesis to $6.0,10.0$, and $19.1 \%$ when fenhexamid is applied at 3, 7, and 14 DAA, respectively. Delaying the first application even 3 days after flower opening increases the predicted level of Botrytis fruit rot. Actual disease incidence data suggest an even greater increase during this interval (Table 2). Control is increasingly compromised as the time of application is delayed. Therefore, protectant fungicides such as fenhexamid should be applied frequently during bloom periods to protect susceptible flowers that open on a daily basis. Protecting every flower, however, is not feasible due to technical problems in achieving complete spray coverage. In addition, frequent fungicide applications are difficult to coordinate with 2- to 3-day harvest intervals common in strawberry, and undesirable for economic, environmental, health, safety, and regulatory reasons. Research is needed to characterize bloom periods, so that a minimum number of applications can be timed to protect a maximum number of newly opened flowers. Phenological landmarks for predicting peak bloom periods are not readily apparent, but may be possible for specific cultivars in localized growing regions (12).
The determination of fungicide spray intervals in strawberry is influenced by pathogen(s), cropping systems, environmental factors, label restrictions, and cost. However, these experiments and previous studies (20) suggest that this interval should not exceed 7 days in Florida. Kamoen and Jamart (16) also recommended frequent applications during flowering periods based on rates of penetration of strawberry petals by $B$. cinerea. Other investigators have confirmed the efficacy of regular fungicide applications during bloom periods $(1,29)$.

Emasculation and petal removal were included in this study to test the hypothesis that removal of putative infection courts would decrease the incidence of Botrytis fruit rot. Emasculation was the most efficacious, reducing disease incidence an average of $55 \%$ compared with the untreated control (Table 2). Moreover, the efficacy of emasculation may have been underestimated, since emasculated fruit lack the protection provided by the calyx when in direct contact with Botrytis diseased fruit or other infected tissues (J. Mertely, unpublished data). Powelson (23) emasculated young fruit 5 to 10 days after fertilization in the greenhouse and reported similar reductions in Botrytis fruit rot. Surprisingly, petal removal did not consistently reduce Botrytis incidence in our study. Petal removal reduced diseased incidence $38 \%$ in $1999-2000$, but a $10 \%$ reduction in 2000-2001 was not statistically significant (Table 2). Most petals abscise and fall from the fruit naturally. Petals that are colonized by Botrytis and trapped under the calyx may initiate infections but are not the principal cause of Botrytis fruit rot.

The marked reduction in disease incidence produced by emasculation supports the hypothesis that stamens play a dominant role in the infection of strawberry fruit by $B$. cinerea $(5,13,23)$. When a flower is emasculated, petals, sepals, and stamens are removed. Petals probably account for a relatively small proportion of Botrytis fruit rot infections. Sepals are not highly colonized $(12,23)$, do not begin senescing until after harvest, and are not thought to be involved in the infection process (28). Stamens, on the other hand, are rapidly colonized by $B$. cinerea $(5,23)$. Moreover, higher levels of Botrytis fruit rot have been observed in staminate genotypes than in related pistillate genotypes, which lack stamens (24). Although emasculation is not a practical technique for the control of Botrytis fruit rot, the striking efficacy of this practice suggests that some stamen characteristics may contribute to disease resistance. These may include delayed senescence, rapid shedding of anthers, or an ability to impede movement of the infection through the filament into basal tissues of the calyx and receptacle.
Symptoms of Botrytis fruit rot are commonly observed as the fruit ripens or after harvest $(7,23)$. However, B. cinerea also blights strawberry flowers (13) and may cause lesions at any stage of fruit development (28). No flower blighting was observed in our experiments, and relatively few fruit were visibly infected 14 DAA. In general, symptoms of Botrytis fruit rot developed after 14 days, and these were observed 6 to 14 days later at harvest. Most cases of early symptom expression occurred during experiments 1 and 3 in 19992000 (Table 1). Further studies are needed to determine if fruit developing during the first bloom period (as in experiment 1) or fruit exposed to natural rainfall (experiment 1) or overhead irrigation (experiment 3) are physiologically predisposed to rapid disease development. The latter theories are supported by a report of a strong positive correlation between rainfall during the postbloom period and the incidence of Botrytis fruit rot (29).

In this study, experiments were initiated by tagging flowers at anthesis and applying treatments to individual flowers and fruit at defined intervals postanthesis. Starting each experiment with newly opened flowers synchronized the chronological age of the experimental units and fixed the experimental period. This design minimized the confounding effects of chronological age, physiological variability, and changing environment, and was successfully used to evaluate the relationship between time of fungicide application and Botrytis fruit rot control. Individual flower evaluations could also be used to evaluate and compare products for the control of Botrytis fruit rot on strawberry. Instead of spraying blocks of plants and harvesting fruit for an entire season, treatments could be applied to individual flowers or fruit and evaluated for efficacy at defined intervals after treatment or at harvest. This technique may have applications in other host-pathogen systems for epidemiological research and product testing.

\section{LITERATURE CITED}

1. Bédard, R., and Lachance, R. O. 1970. Controle de la moisissure grise de la fraise. (In French with English summary) Phytoprotection 51:72-77.

2. Bennett, M. 1972. Field control of strawberry fruit rot (Botrytis cinerea $\mathrm{Fr}$.) by fungicides (II). J. Hortic. Sci. 47:321-327.

3. Blacharski, R. W., Bartz, J. A., Xiao, C. L., and Legard, D. E. 2001. Control of postharvest Botrytis fruit rot with preharvest fungicide applications in annual strawberry. Plant Dis. 85:597-602.

4. Braun, P. G., and Sutton, J. C. 1987. Inoculum sources of Botrytis cinerea in fruit rot of strawberries in Ontario. Can. J. Plant Pathol. 9:1-5.

5. Bristow, P. R., McNicol, R. J., and Williamson, B. 1986. Infection of strawberry flowers by Botrytis cinerea and its relevance to grey mould development. Ann. Appl. Biol. 109:545-554.

6. Bulger, M. A., Ellis, M. A., and Madden, L. V. 1987. Influence of temperature and wetness 
duration on infection of strawberry flowers by Botrytis cinerea and disease incidence of fruit originating from infected flowers. Phytopathology 77:1225-1230.

7. Ceponis, M. J., Cappellini, R. A., and Lightner, G. W. 1987. Disorders in sweet cherry and strawberry shipments in the New York market, 1972-1984. Phytopathology 71:472475.

8. Dennis, C. 1975. Effect of pre-harvest fungicides on the spoilage of soft fruit after harvest. Ann. Appl. Biol. 81:227-234.

9. Ellis, M. A., and Grove, G. G. 1982. Fruit rots cause losses in Ohio strawberries. Ohio Rep. 67:3-4.

10. Hancock, J. F., Scott, D. H., and Lawrence, F. J. 1996. Strawberries. Pages 419-470 in: Fruit Breeding. Vol. II, Vine and Small Fruits. John Wiley \& Sons, New York.

11. Jarvis, W. R. 1962. The infection of strawberry and raspberry fruits by Botrytis cinerea Fr. Ann. Appl. Biol. 50:569-575.

12. Jarvis, W. R. 1969. The phenology of flowering in strawberry and raspberry in relation to grey mould control. Hortic. Res. 9:8-17.

13. Jarvis, W. R., and Borecka, H. 1968. The susceptibility of strawberry flowers to infection by Botrytis cinerea Pers. Ex Fr. Hortic. Res. 8:147-154.

14. Jordon, V. W. L. 1973. The effects of prophylactic spray programmes on the control of preand post-harvest diseases of strawberry. Plant
Pathol. 22:67-70.

15. Jordan, V. W. L. 1978. Epidemiology and control of fruit rot Botrytis cinerea on strawberry. Pflanzenschutz-Nachr. 31:1-10.

16. Kamoen, O., and Jamart, G. 1974. Problems of Botrytis fruit rot control on strawberry. Int. Symp. Fytofarm Fytiat. 26(pt. 2):1107-1119.

17. Krüger, B. W., Etzel, W., and Goehrt, A. 1999. Fenhexamid (KBR 2738) - A new botryticide from a new chemical class. (In German with English summary) Pflanzenschutz Nachr. Bayer 99:123-129.

18. Legard, D. E., Bartz, J. A., and Chandler, C. K. 1997. The control of strawberry diseases by sanitation. Int. Strawberry Symp., 3rd. Acta Hortic. 439:917-921.

19. Legard, D. E., Xiao, C. L., Mertely, J. C., and Chandler, C. K. 2000. Effects of plant spacing and cultivar on incidence of Botrytis fruit rot in annual strawberry. Plant Dis. 84:531-538.

20. Legard, D. E., Xiao, C. L., Mertely, J. C., and Chandler, C. K. 2001. Management of Botrytis fruit rot in annual winter strawberry using captan, thiram, and iprodione. Plant Dis. 85:31-39.

21. Maas, J. L., and Smith, W. L. 1972. Preharvest fungicide treatments for increasing yields and controlling pre- and postharvest fruit decay of strawberry. Plant Dis. Rep. 56:296-299.

22. Mertely, J. C., and Legard, D. E. 2001. Control of Botrytis fruit rot with fenhexamid in relation to developmental stages of strawberry flowers and fruit. (Abstr.) Phytopathology 91:S62.

23. Powelson, R. L. 1960. Initiation of strawberry fruit rot caused by Botrytis cinerea. Phytopathology 50:491-494.

24. Simpson, D. W. 1991. Resistance to Botrytis cinerea in pistillate genotypes of the cultivated strawberry Fragaria ananassa. J. Hortic. Sci. 66:719-723.

25. Sommer, N. F., Fortlage, R. J., Mitchell, F. G., and Maxie, E. C. 1973. Reduction of postharvest losses of strawberry fruits from gray mold. J. Am. Soc. Hortic. Sci. 98:285-288

26. Sosa-Alvarez, M., Madden, L. V., and Ellis, M. A. 1995. Effects of temperature and wetness duration on sporulation of Botrytis cinerea on strawberry leaf residues. Plant Dis. 79:609-615.

27. Sutton, J. C. 1990. Epidemiology and management of Botrytis leaf blight of onion and gray mold of strawberry: A comparative analysis. Can. J. Plant Pathol. 12:100-110.

28. Sutton, J. C. 1998. Botrytis fruit rot (gray mold) and blossom blight. Pages 28-31 in: Compendium of Strawberry Diseases. 3rd ed. J. L. Maas, ed. American Phytopathological Society, St. Paul, MN

29. Wilcox, W. F., and Seem, R. C. 1994. Relationship between strawberry gray mold incidence, environmental variables, and fungicide applications during different periods of the fruiting season. Phytopathology 84:264-270. 